\section{OAK RIDGE \\ NATIONAL LABORATORY}

MARTIN MARIETTA
ASSESSMENT OF THE NEED FOR DUAL INDOOR/OUTDOOR WARNING SYSTEMS AND ENHANCED TONE ALERT TECHNOLOGIES IN THE CHEMICAL STOCKPILE EMERGENCY PREPAREDNESS PROGRAM

by

John H. Sorensen

\section{MANAGED BY}

MARTIN MARIETTA ENERGY SYSTEMS, INC.

FOR THE UNITED STATES

DEPARTMENT OF ENERGY 
This report has been reproduced directly from the be'st available copy.

Available to DOE and DOE contractors from the Office of Scientific and Technical Information, P.O. Box 62, Oak Ridge, TN $3783 \%$; prices available from (615) 576-8401, FTS 626-8401.

Available to the public from the National Technical Information Service, U.S Department of Commerce, 5285 Port Royal Rd., Springfield, VA 22161.

This report was prepared as an account of work sponsored by an agency of the United States Government. Neither the Unitiod States Government nor any agency thereof, nor any of their employees, makes any warranty, express or implied, or assumes any legal liability or responsibility for the eccuracy, com. pleteness, or usefulness of any information, apparatus, product, or process disclosed, or represents that its use would not infringe privately owned rights. Reference herein to any specific commercial product, process, or service by trade name, trademark, manufacturer, or otherwise, does not necessarily constitute or imply its ondorsement, recommendation, or favoring by the United States Government or any agency thereof. The views and opinions of authors expressea herein do not necessarily state or reflect those of the United States Government or any agency thereot. 


\section{Assessment of the Need for Dual Indoor/Outdoor Warning Systems and Enhanced Tone Alert Technologies in the Chemical Stockpile Emergency Preparedness Program}

John H. Sorensen

May 1992

Prepared by the Oak Ridge National Laboratory Oak Ridge, Tennessee 37831-6285 managed by

Martin Marietta Energy Systems, Inc. under Contract No. DE-AC05-840R21400 


\section{TABLE OF CONTENTS}

LIST OF FIGURES AND TABLES...........................................

LIST OF ACRONYMS ...................................................

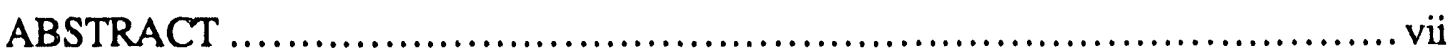

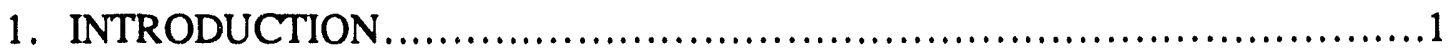

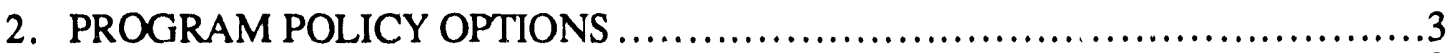

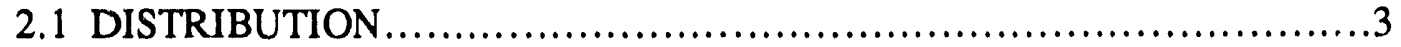

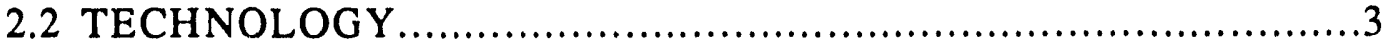

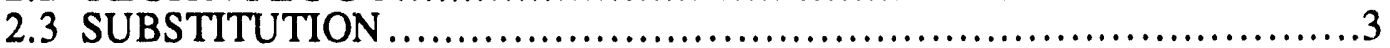

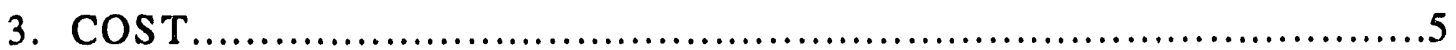

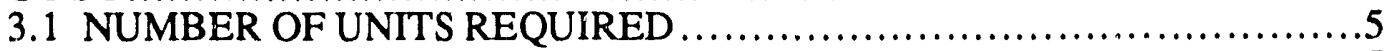

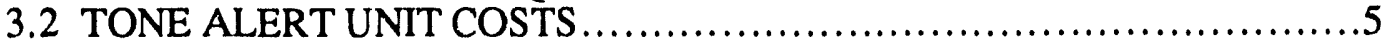

3.2.1 Special Unit Costs.....................................................5

3.2.2 Commercial Unit Costs...................................................6

3.2.3 Budget Special Unit Costs .................................................6

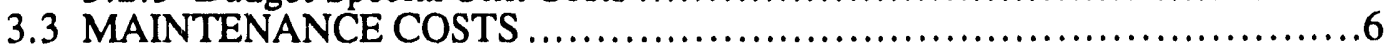

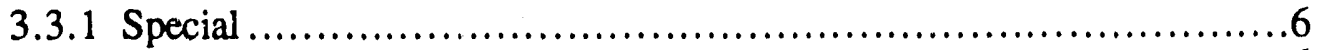

3.3.2 Commercial ......................................................6

3.3.3 Budget Special..................................................

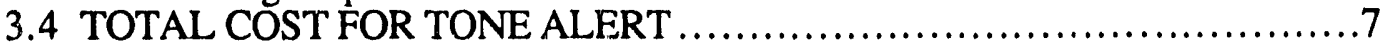

3.5 COST FOR THE SIREN SUBSTITUTION OPTION $\ldots \ldots \ldots \ldots \ldots \ldots \ldots \ldots \ldots . \ldots$

3.5.1 20-dB Option .................................................

3.5.2 High Population Option ......................................... 7

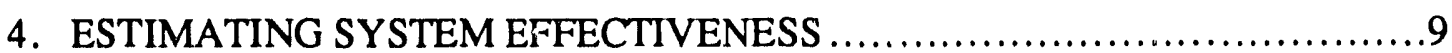

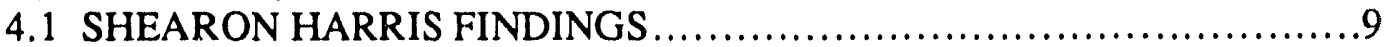

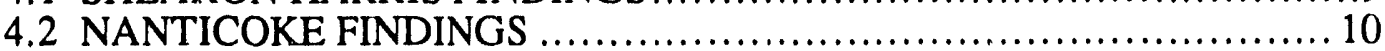

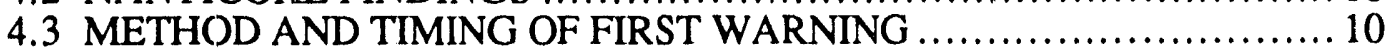

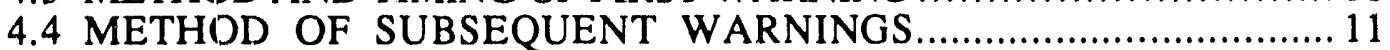

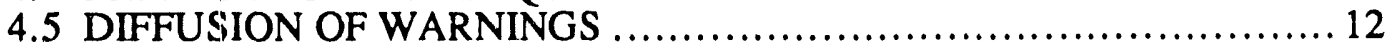

4.6 ANALYSIS OF SYSTEM EFFECTIVENESS ............................... 14

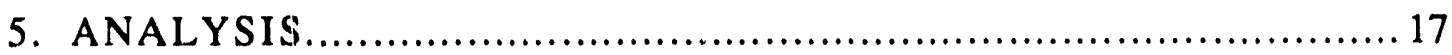

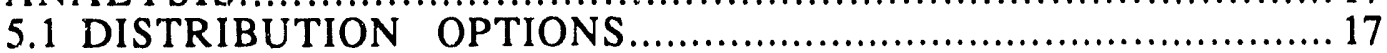

5.2 TECHNOLOGY OPTIONS .............................................. 17

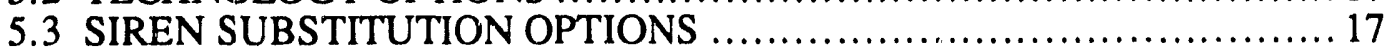

5.3.1 Raise the Standard................................................. 17

5.3.2 Substitute Outdoor Sirens ........................................ 17

6. CONCLUSIONS AND RECOMMENDATIONS .......................... 19

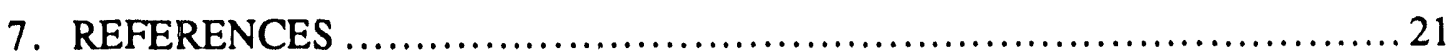




\title{
LIST OF FIGURES AND TABLES
}

Table 1. Estimates of units required...........................................5

Table 2 Costs of tone alert units over 8-year period....................................

Table 3. Source and mean time of first warning............................... 11

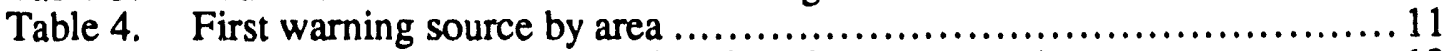

Table 5. Method of subsequent warning (in column percents) ................... 12

Table 6. Total receiving warning by source .................................... 13

Fig. 1 Diffusion of warning at Nanticoke....................................... 13

Table 7. Estimated 15-min notification rates nighttime (expected percent warned).. 15

Table 8. Estimated 15-min notification rates daytime (expected percent warned) ... 15

Table 9. Summary of estimated costs and benefits.............................. 19

\section{LIST OF ACRONYMS}

\author{
$A \& N \quad$ alert and notification \\ CDC Centers for Disease Control \\ CSDP Chemical Stockpile Disposal Program \\ CSEPP Chemical Stockpile Emergency Preparedness Program \\ EPZ emergency planning zone \\ FEMA Federal Emergency Management Agency \\ IRZ immediate response zone \\ TA tone alert
}




\begin{abstract}
The need for a dual indoor/outdoor waming system as recommended by the program guidance and Alert and Notification (A\&N) standard for the Chemical Stockpile Emergency Preparedness Program is analyzed in this report. Under the current program standards, the outdoor warning system consists of omnidirectional sirens and the new indoor system would be an enhanced tone alert (TA) radio system. This analysis identifies various tone-alert technologies, distribution options, and alternative siren configurations. It also assesses the costs and benefits of the options and analyzes what appears to best meet program needs.

Given the current evidence, it is recommended that a 10-dB siren system and the special or enhanced TA radio be distributed to each residence and special institution in the immediate response zone as preferred the A\&N standard. This approach minimizes the cost of maintenance and cost of the TA radio system while providing a high degree of reliability for indoor alerting. Furthermore, it reaches the population (residential and institutional) in the greatest need of indoor alerting.
\end{abstract}




\section{INTRODUCTION}

The Chemical Stockpile Disposal Program (CSDP) was initiated in response to the 1986 Congressional mandate (by Public Law 99-145) to rid the United States of the aging stocks of chemical munitions by the year 1992. Many of the weapons had been in storage since the early 1940s. These munitions, located at eight army depots around the country, contain the chemical nerve agents VX and GB and the blistering agents $\mathrm{H}$, $\mathrm{HD}$, and $\mathrm{HT}$ (commonly called mustard gas), all of which are highly toxic to humans upon inhalation or skin contact. A technology using high-temperature incineration is to be used for the disposal of weaponry.

The law mandating disposal requires destruction in a manner that maximizes the health and safety of the public. Chemical agents, however, are among the most toxic hazardous materials in existence and are stored in large quantities. The probabilistic risk analysis for the disposal program identified a number of credible accident scenarios that could result in fatalities. The Final Programmatic Environmental Impact Statement for the CSDP (U.S. Army 1988) found that emergency planning for an accident was inadequate in the communities surrounding storage sites. The Army's record of decision subsequently committed the Army to enhanced emergency planning (Ambrose 1988). Currently, programs are being implemented at the eight sites. The Chemical Stockpile Emergency Preparedness Program (CSEPP), jointly managed by the Army and the Federal Emergency Management Agency (FEMA), has the ambitious goal of achieving state-of-the-art plans that provide maximum public protection.

Under the guidance of the planning subcommittee of CSEPP, a planning guidance document was prepared (Oak Ridge National Laboratory and Schneider Engineers 1990). The planning guidance provides general guidelines for implementing CSEPP. Program standards are also being developed to provide more detailed planning requirements. These requirements must be met by participants in the program to receive CSEPP funding for emergency systems. One of the areas in which detailed standards have been prepared is alert and notification (A\&N) systems, often referred to as public warning systems.

This report analyzes the need for a dual indoor-outdoor warning system as recommended by the program guidance and A\&N standard for the CSEPP. Under the current program standards, the outdoor warning system consists of omni-directional sirens. The indoor system would be an enhanced tone alert (TA) radio system. This analysis identifies various TA technologies, distribution options, and alternative siren configurations. It also assesses the costs and benefits of the options and analyzes what appears to best meet program needs. In doing so, it addresses several questions.

1. Will an outdoor siren system provide adequate nighttime alerting in summer or winter conditions when buildings are not open?

2. Will commercial off-the-shelf TA radios be adequate?

3. What benefits will be gained from an enhanced TA technology?

4. What distribution should be made of indoor alert devices?

5. Can an outdoor system be designed to replace indoor alerting? 


\section{PROGRAM POLICY OPTIONS}

We have specified a limited set of options to use in the analysis. These were chosen to reflect viable program options that appear to be feasible at present. The baseline for the program is an outdoor siren system with sound levels that are $10 \mathrm{~dB}$ over ambient noise levels. The options vary for the distribution policy for TA radios, the technologies available in TA radios, and the substitution of a different outdoor system for the indoor alerting system.

\subsection{DISTRIBUTION}

Three different distribution options for indoor alerting units have been specified:

1. Provide a single unit to each private household and institution within the immediate response zone (IRZ) (with option for others to buy at cost).

2. Provide multiple units to each household and institution and to all inhabited buildings such as shops and industries within the IRZ.

3. Provide a single unit to all households/institutions and to inhabited buildings within the IRZ.

\subsection{TECHNOLOGY}

Although a variety of TA technologies can be specified, three options were chosen for review:

1. The special TA unit identified in the CSEPP Alert and Notification (A\&N) standards. This unit is designed to have high reliability and low maintenance costs. Its features are outlined in the A\&N standards (Anstech, et al. 1990).

2. A commercial off-the-shelf unit which is activated by the National Oceanic and Atmospheric Administration weather system.

3. A budget version of the special unit that does not have any of the special features except for a unique activation frequency.

\subsection{SUBSTITUTION}

Two substitution options have been identified:

1. Raise the standard for outdoor sirens from $10 \mathrm{~dB}$ to $20 \mathrm{~dB}$ over ambient. The rationale is that the higher sound output would solve the problem of nighttime alerting.

2. Substitute outdoor sirens for indoor alerting in high population areas and distribute TA radios in less populated areas. This would invrlve getting a noise level output from sirens in populated areas that would penetrate buildings and arouse people who are asleep (Carter 1990). The noise level required would be $85 \mathrm{~dB}$ at the wall of a house to achieve indoor alerting (Long 1990). The feasibility of indoor notification with outdoor sirens is not currently known. 


\section{3. $\operatorname{Cos} T$}

\subsection{NUMBER OF UNITS REQUIRED}

Table 1 contains estimates of the number of units required for each site under the three different distribution policies. These estimates were based on population estimates at each site and on field experience in developing emergency plans. They were chosen by consensus of the planning subcommittee, but more precise estimates will be required prior to procurement.

Table 1. Estimates of units required

\begin{tabular}{lccc}
\hline \multicolumn{1}{c}{ Site } & $\begin{array}{c}\text { 2. Multiple } \\
\text { units to homes } \\
\text { and inhabited } \\
\text { buildings }\end{array}$ & $\begin{array}{c}\text { 3. Sne unit } \\
\text { to each home } \\
\text { homes and } \\
\text { inhabited } \\
\text { buildings }\end{array}$ \\
\hline Aberdeen Proving Ground & 23,000 & 50,000 & 37,500 \\
Anniston Army Depot & 18,000 & 30,000 & 22,500 \\
Lexington-Blue Grass Army Depot & 10,000 & 40,000 & 30,000 \\
Newport Army Ammunition Plant & 3,000 & 7,000 & 5,250 \\
Pine Bluff Arsenal & 30,000 & 70,000 & 52,500 \\
Pueblo Depot Activity & 100 & 200 & 150 \\
Tooele Army Depot & 300 & 300 & 225 \\
Umatilla Depot Activity & 5,000 & 8,000 & $-6,000$ \\
Total & 89,400 & 205,300 & 153,975 \\
\hline
\end{tabular}

The choice of TA technology would nct impact the number of units required. Raising the standard for outdoor sirens from $10 \mathrm{~dB}$ to $20 \mathrm{~dB}$ over ambient would involve increasing the number of sirens about $300-400 \%$ over existing estimates (Long 1990), and would eliminate the need for TA radios.

Outdoor substitution in high population areas is estimated to result in a $50 \%$ reduction in units required for any of the three distribution options, and would add three to six sirens per site (Carter 1990). This estimate requires additional substantiation on a site-by-site basis.

\subsection{TONE ALERT UNIT COSTS}

The following sections estimate the cost of a TA unit, including distribution.

\subsubsection{Special Unit Costs}

It is estimated that a special unit (one with a unique frequency and special features) would cost $\$ 125$ based on cost estimates developed by SE Technologies. 
Some of the marginal costs of the special features are as follows:

\begin{tabular}{lc} 
Feature & Marginal cost \\
\hline Lithium battery $^{a}$ & $\$ 15$ \\
AC plug spring clip $^{a}$ & 1 \\
LED battery condition indicator $^{a}$ & 10 \\
110 volt output $^{a}$ & 7 \\
Strobe output jack $^{a}$ & 1 \\
External antenna jack $^{a}$ & 1 \\
LED test status indicator $^{a}$ & 10 \\
Adjustable message volume $_{\text {Visual activation indicator }}$ & 7 \\
Total & 1 \\
\hline
\end{tabular}

${ }^{a}$ Essential items to achieve high reliability and low maintenance.

Source: Long, J. 1990 (SE Technologies) Memo to J. Sorensen, Oak Ridge National Laboratory, Oak Ridge, Tenn., August 28.

\subsubsection{Commercial Unit Costs}

It is estimated that a commercial unit (such as a Radio Shack unit) would cost $\$ 30$ based on cost estimates developed by SE Technologies.

\subsubsection{Budget Special Unit Costs}

It is estimated that a budget special unit (one with a unique frequency but without the special features listed in Sect. 3.2.1) would cost $\$ 75$ based on cost estimates developed by SE Technologies.

\subsection{MAINTENANCE COSTS}

It is assumed that maintenance wr uld be done over an 8-year period.

\subsubsection{Special}

Annual cost for the special unit would be $\$ 1.50$ per unit. The total cost over the program would be $\$ 12$ per unit. It is assumed that the design features would eliminate the need for yearly inspection. If we assume that $5 \%$ of the radio units would require maintenance each year due to a problem, the yearly cost would be $\$ 1.50$ per unit. The cost over an 8-year period would be $\$ 12$.

\subsubsection{Commercial}

Annual cost for the commercial unit would be $\$ 30$ per unit. The total cost over the program would be $\$ 240$. It is assumed that one visit per year would be required per unit for inspection, verification of working condition, and battery replacement. The estimated per unit cost is based on an estimate by ERCE, Inc., for Oak Ridge National Laboratory (ORNL) (ERCE no date). 


\subsubsection{Budget Special}

The annual cost of the budget special would be $\$ 30$ per unit. The total cost over the program would be $\$ 240$. This is the same as for the commercial unit.

\subsection{TOTAL COST FOR TONE ALERT}

Tables 2 shows estimates of the cost over an 8-year period.

Table 2. Costs of tone alert units over 8-year period

\begin{tabular}{|c|c|c|c|c|}
\hline \multirow[b]{2}{*}{ Type } & \multirow[b]{2}{*}{ Number of units } & \multicolumn{3}{|c|}{ Cost $(\$ M)$} \\
\hline & & Capital & Maintenarice & Totala \\
\hline $\begin{array}{l}\text { Special } \\
\text { (\$125/unit) }\end{array}$ & $\begin{array}{r}90,000 \\
150,000 \\
200,000\end{array}$ & $\begin{array}{l}\$ 11.3 \\
\$ 18.8 \\
\$ 24\end{array}$ & $\begin{array}{l}\$ 1.1 \\
\$ 1.8 \\
\$ 2.4\end{array}$ & $\begin{array}{l}\$ 13 \\
\$ 21 \\
\$ 27\end{array}$ \\
\hline $\begin{array}{l}\text { Commercial } \\
\text { (\$30/unit) }\end{array}$ & $\begin{array}{r}90,000 \\
150,000 \\
200,000\end{array}$ & $\begin{array}{l}\$ 2.7 \\
\$ 4.5 \\
\$ 6\end{array}$ & $\begin{array}{l}\$ 21.6 \\
\$ 36 \\
\$ 48\end{array}$ & $\begin{array}{l}\$ 25 \\
\$ 41 \\
\$ 54\end{array}$ \\
\hline $\begin{array}{l}\text { Budget special } \\
\text { (\$75/unit) }\end{array}$ & $\begin{array}{r}90,000 \\
150,000 \\
200,000\end{array}$ & $\begin{array}{l}\$ 6.8 \\
\$ 11.3 \\
\$ 15\end{array}$ & $\begin{array}{l}\$ 21.6 \\
\$ 36 \\
\$ 48\end{array}$ & $\begin{array}{l}\$ 29 \\
\$ 38 \\
\$ 63\end{array}$ \\
\hline
\end{tabular}

${ }^{a}$ Rounded up to nearest million dollars.

Based on these estimates, the special TA technology is the best solution if maintenance costs are assumed to be covered by the program.

\subsection{COST FOR THE SIREN SUBSTITUTION OPTION}

\subsubsection{0-dB Option}

Raising the outdoor siren standard to $20 \mathrm{~dB}$ above ambient noise levels would increase the cost of the outdoor system by 300-400\% (Long 1990). Based on an estimate of \$5.3 M (Long 1990), this option would cost about \$16-21 M.

\subsubsection{High Population Option}

It is estimated that the costs for installing outdoor sirens in populated areas that would achieve an $85-\mathrm{dB}$ sound level would lower the costs of TA radios by $50 \%$ and raise the cost of the sirens by about $\$ 1.5 \mathrm{M}$ (48 extra sirens maximum $\times \$ 30 \mathrm{~K}$ each) (Carter 1990). 


\section{ESTIMATING SYSTEM EFFECTIVENESS}

This section analyzes the effectiveness of the program alternatives.

Effectiveness is defined by the portion of the population that is alerted and notified by the system in a rapid (15-min) time frame. It starts with defining the methodology used to measure system effectiveness for the Shearon Harris Nuclear Power Plant, introduces new data on warning system effectiveness collected in Nanticoke, Pennsylvania, and analyzes the options discussed earlier based on these two sets of findings.

\subsection{SHEARON HARRIS FINDINGS}

The most significant debate on what constitutes a state-of-the-art A\&N system came in Atomic Safety and Licensing Board proceedings on the Shearon Harris Nuclear Power Plant. In their final decision the board defined what constitutes "essentially $100 \%$ notification within $15 \mathrm{~min}$ in the first 5 miles of the Harris emergency planning zone" $(23$ NRC 294, 1986). In this matter the board required the utility to prove that over $95 \%$ of the people within 5 miles would receive a warning in summer nighttime conditions, one of the most difficult warning times. The utility could not do so by relying solely on a siren system. To exceed the $95 \%$ level, commercial TA radios as well as siren alert were proposed for all households in the 5-mile radius. The board accepted this plan as exceeding $95 \%$ notification.

The basic logic behind the ruling was as follows. The board accepted a method for calculating sleep arousal by sirens. In this method a sound level in a bedroom is calculated based on the attenuation of sound from outside to inside. The method assumed four 3-min siren soundings. It was calculated that the probability of arousal for an individual was $62 \%$. Household size was taken into account as it was assumed that one person over 12 years old hearing the sirens would wake others in the house. Based on the household size distribution, it was calculated that $83.5 \%$ of the households would be alerted. An additional $1 \%$ of the unalerted household would have someone awake at the time of the sounding, resulting in $84.5 \%$ alerting. It was assumed that those alerted would seek notification.

The board, based on evidence from other disasters, accepted that $50 \%$ of the households alerted would contact someone else after receiving the warning (informal notification). Thus, they held that $42.5 \%$ would notify another household. Since $15.5 \%$ of the households had not yet been warned, an additional $6.7 \%$ would be warned by someone who had received the warning, for a total of $91 \%$ notificationstill ton low to satisfy the $95 \%$ requirement. It was assumed that route alerting would not be feasible in a $15-\mathrm{min}$ time frame.

If TA radios were also used, however, the board accepted that $83 \%$ of the households would receive an alert from a TA radio, based on the experience with the Ft. St. Vrain Nuclear Power Plant in Colorado, which uses TA radios and one siren in its 5-mile emergency planning $\mathrm{zcne}$ (EPZ). Therefore, it was concluded that of the $9 \%$ not hearing a warning using a siren alone, $7.5 \%$ would hear a TA radio, raising the alert rate to $98.5 \%$.

The major problem in this method for calculating siren effectiveness was the lack of distinction and often confusion over alert versus notification. The calculation of the $84.5 \%$ arousal by siren refers to the alert function only. At no time was the rate for the alert component of the siren system calculated. The informal and TA rates implicitly refer to both $A \& N$ components, although with informal notification officials have no control over the message contents. 


\subsection{NANTICOKE FINDINGS}

The warning and evacuation at Nanticoke, Pennsylvania, was caused by a fire that threatened to burn toxic chemicals onsite at the Spencer Metal Processing Plant. The accident occurred about 15 min after midnight on March 24, 1987. Local officials were somewhat slow in assessing the gravity of the situation. After consulting the Chemical Transport Engineering Center, which is a part of the Chemical Manufacturers Association, officials decided to act on the worst-celse scenario. The official evacuation began at about 2:20 a.m. Records indicate the sirens for the Susquehanna Nuclear Power Plant were sounded at 2:21 a.m. and the Emergency Broadcast System broadcasts commenced at 2:30 a.m. It is likely that due to fire truck responses the public was hearing other sirens from 12:30 on. The evacuation was a staged effort. The city was divided into quadrants. The quadrant nearest the plant was the first to evacuate. At 2:50 a.m. official decicied to evacuate the northwest and west quadrants of the city. At 3:42 a.m. the evacuation of the remainder of Nanticoke began. Thus, we can identify three distinct geographically determined groups of evacuees.

Shortly after the incident, the Centers for Disease Control (CDC), in the Department of Health and Human Services, Atlanta, Georgia. conducted a telephone survey in Nanticoke. The general results of this survey along with the methodology are published elsewhere (Duclos, et al. no date; Duclos, et al. 1989).

\subsection{METHOD AND TIMING OF FIRST WARNING}

The CDC survey described ways in which people were warned to evacuate. These methods included sirens, officials going through the streets with loudspeakers, officials going door-to-door, friends or relatives going to someone's door, telephone calls from friends or relatives, radio, and television. In fact, these tre all common means that are used to warn people in emergencies (Lindell and Perry 1987; Sorensen and Mileti 1990).

Perhaps the most significant aspect of the warning is that the town of Nanticoke is within the 10-mile EPZ for the Susquehanna Nuclear Power Plant. As a result, the town is blanketed with coverage by the sirens that would be used to alert the public to a potential emergency at that plant. This alert system consists of 110 sirens and includes 44 Federal Signal Thunderbolt 1000s, 50 FS STH10s, and 16 FS 5s. The sirens are rated at 125,115 , and $105 \mathrm{~dB}$ nispectively. On July 30,1986 , a test of the sirens was made at 11:55 a.m., and a telephone survey was conducted to determine how many people heard the sirens. Results indicated that $76.5 \%$ of those persons polled heard the sirens. No data is available to ascertian the warning rate within the city of Nanticoke, but there is no reason to believe that it would be significantly different.

Table 3 presents the CDC survey data regarding how people first learned of the need to evacuate, which is the notification aspect of the warning process. It also presents the mean time which people cited as when they first were warned. The sirens were effective in providing notification to about one third of the sample. Informal notification, was the major means of notification, with about $40 \%$ hearing from a friend or relative in person or over the phone. The media-not unexpectedly, given the time of day-was attributed with $5 \%$ of the initial waming. Officials going door-to-door or with loudspeakers accounted for $20.5 \%$ of the notification.

When the mean times of warning are compared we see that media alen was substantially slower than other mearıs. Door-to-door provided the earliest notification on average, while loudspeakers were somewhat slower. The other forms fall in between but are not substantially different from one another. 
Table 3. Source and mean time of first warning

\begin{tabular}{lcc}
\hline \multicolumn{1}{c}{ System } & Percent warned $^{a}$ & Mean time warned \\
\hline Sirens & 34.1 & \\
Route: loudspeakers & 15.7 & $2: 30$ a.m. \\
Route: door-to-door & 4.8 & $2: 45$ a.m. \\
Informal: door-to-door & 18.6 & $2: 14$ a.m. \\
Informal: telephone & 21.5 & $2: 24$ a.m. \\
Media (radio or television) & 5.2 & $2: 37$ a.m. \\
\hline
\end{tabular}

aPercent of sample responding to the question with missing values excluded.

In Table 4, we have collapsed warning source into four majcr categoriessirens, route, informal, and media - to examine geographical differences in the waming process. The areas represent the first, second, and third areas of the city to be. evacuated in sequence. Indeed, the table shows significant differences among the three areas. In area 1, route alerting was much more prominent than in the other two areas. In areas 2 and 3 , informal notification was much more evident than in area 1 . The role of sirens was similar in areas 1 and 3 and was slightly less important in area 2. Although the media played a minor role in the intial notification, their role was larger in areas 2 and 3 than in area 1.

Table 4. First warning source by area

\begin{tabular}{lcccc}
\hline & \multicolumn{3}{c}{ Area } & \\
\cline { 2 - 4 } \cline { 5 - 6 } Source & One & Two & Three & $\frac{\text { Total } a(\mathrm{n})}{36.6}$ \\
\hline Sirens & 37.0 & 26.8 & & 34.5 \\
Route & 36.2 & 18.6 & 10.7 & $(152)$ \\
Informal & 25.4 & 47.4 & 46.3 & $(90)$ \\
Media & 1.5 & 7.2 & 6.3 & $(176)$ \\
Total $(\mathrm{n})$ & 100 & 100 & 100 & $(22)$ \\
& $(138)$ & $(97)$ & $(205)$ & $(440)$ \\
\hline
\end{tabular}

aTotal percentages will differ from previous table due to missing data.

\subsection{METHOD OF SUBSEQUENT WARNINGS}

People usually receive more than one warning in an emergency. The Nanticoke survey allows us to examine which warnings were received subsequent to the initial warning. The results are shown in Table 5. The cells of the table are column percentages that are measured as those receiving a subsequent warning expressed as a percentage of those receiving a first warning from a source. For example, of those receiving a first warning from a siren, $31.3 \%$ also heard the warning from a loudspeaker, and $32.5 \%$ received a warning from a media source. 
Table 5. Method of subsequent warning (in column percents) ${ }^{a}$

\begin{tabular}{lccccc}
\hline & \multicolumn{5}{c}{ Source of first waming } \\
\cline { 2 - 6 } Subsequent warning & $\begin{array}{c}\text { Siren } \\
(n=163)\end{array}$ & $\begin{array}{c}\text { Route } \\
(n=98)\end{array}$ & $\begin{array}{c}\text { Informal } \\
(n=192)\end{array}$ & $\begin{array}{c}\text { Media } \\
(n=25)\end{array}$ & $\begin{array}{c}\text { Total } \\
(n=478)\end{array}$ \\
\hline Siren & 23.9 & 53.1 & 44.3 & 44.0 & 39.1 \\
Route: loudspeakers & 31.3 & 19.4 & 24.0 & 40.0 & 26.4 \\
Route: door-to-door & 11.7 & 04.1 & 06.3 & 24.0 & 08.6 \\
Informal: door-to-door & 23.9 & 09.2 & 10.0 & 12.0 & 14.6 \\
Informal: telephone & 10.4 & 04.1 & 03.6 & 04.0 & 6.1 \\
Media & 32.5 & 03.1 & 17.7 & 12.0 & 19.5 \\
Total & $133.7 b$ & 93.0 & 105.9 & 136.0 & 114.3 \\
\hline
\end{tabular}

${ }^{a}$ As percent of those receiving their first warning.

${ }^{b}$ Does not add to $100 \%$ because multiple responses are possible.

Among the conclusions reached are the following:

- People who initially were warned by sirens or the media received more secondary warnings than people who were warned by route or informal sources.

- Many (44-53\%) who were warned first by non-sirens also heard the sirens.

- The media were a significant secondary warning source for those initially hearing sirens.

- Telephone calls were not a significant subsequent methcd of warning.

Table 6 shows the percent of the sample who reported either a first or subsequent warning from each source. This was calculated by taking the percent who heard the warning as a first source and adding the percentage who heard each source subsequently, but eliminating those who reported hearing a given source first and also subsequently. Overall, we calculate that $65.1 \%$ heard and understood the sirens or at least associated sirens with the accident event during the course of the emergency. A total of about $58 \%$ received an informal notification. Since people departed fairly rapidly, this number is likely lower than has been observed in other emergencies. Fifty-two percent received route notification and $26 \%$ heard a warning from radio or television.

\subsection{DIFFUSION OF WARNINGS}

The data collected allows us to construct diffusion curves for each warning technology. The curves show the cumulative percent of the population receiving the first warning over time by the four major methods of warning. These are shown in Fig. 1 . 
Table 6. Total receiving warning by source

\begin{tabular}{ll}
\hline \multicolumn{1}{c}{ Warning } & Percent \\
\hline Siren & 65.1 \\
Route: loud speakers & 38.9 \\
Route: door & 13.2 \\
Informal: door & 30.5 \\
Informal: telephone & 26.7 \\
Media & 24.9 \\
\hline
\end{tabular}

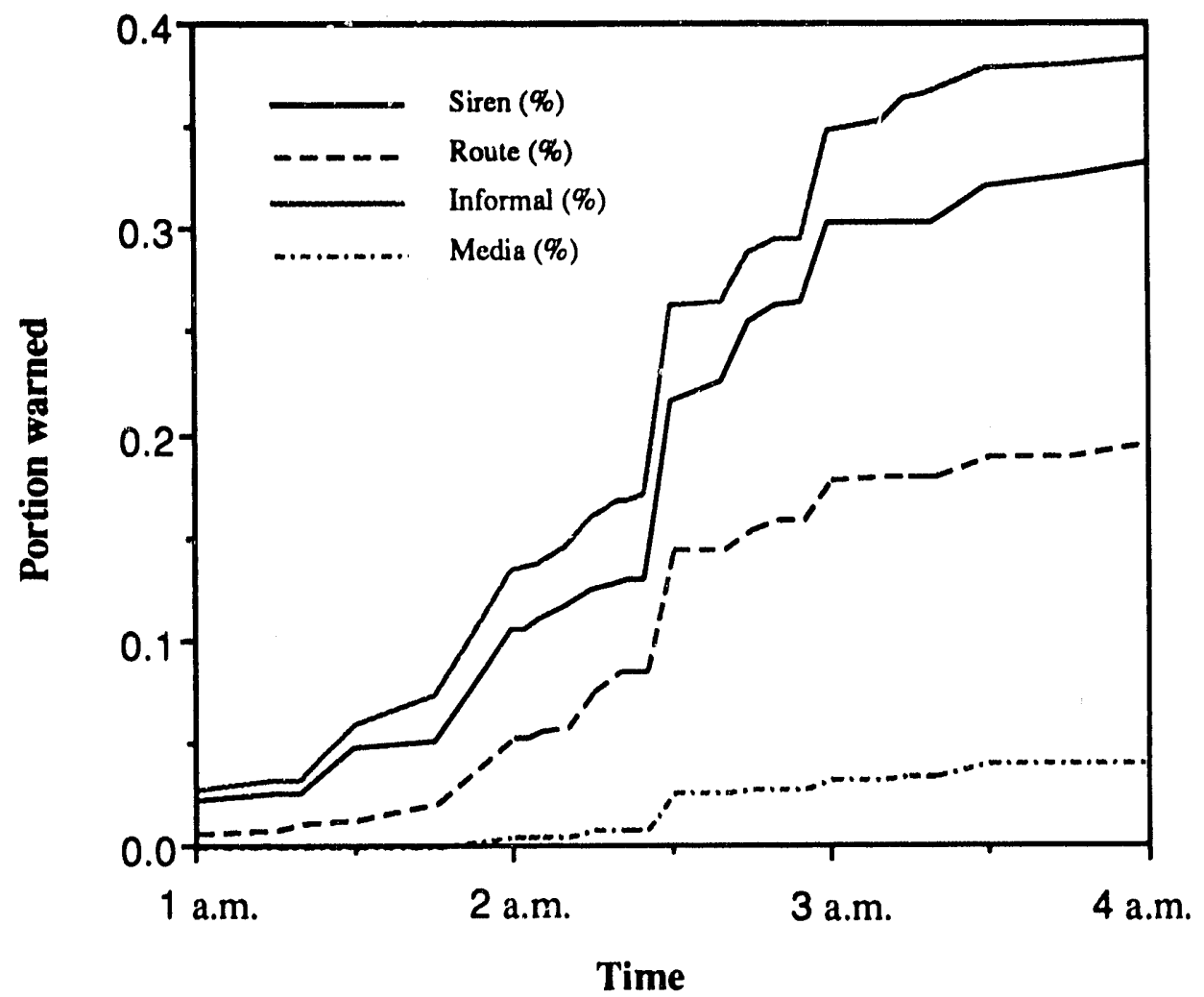

Fig. 1. Diffusion of warning at Nanticoke.

The timing of the diffusion of warnings is very similar for sirens, route, and informal alerting. Some of the early reportings of sirens and route were likely people who htard emergency vehicles responding to the fire. The curves show a steep increase in notification when the official warning activity ensued. By 15 min into the officia! warning, data indicate that about $65 \%$ of the public had been notified. About $22 \%$ of the public had received a siren warning at this point. The remainder had received an informal warning, from route alert or from media. 


\subsection{ANALYSIS OF SYSTEM EFFECTIVENESS}

In this section we calculate warning rates using the approach adopted by the Atomic Safety Licensing Board in the Shearon Harris hearings for nighttime and daytime notification. The assumptions used reflect our estimates of the most likely warning rates given available data and knowledge. For the nighttime scenario we assume a $35 \%$ siren notification after $15 \mathrm{~min}$, which is in line with the Nanticoke data. This was estimated as follows. First, after $15 \mathrm{~min}$ the Nanticoke data indicate about $22 \%$ were alerted by sirens. It is likely, however, that some of those being alerted by route notification would have also heard the sirens. Since $53 \%$ of those notified by route alert were also alerted by sirens and about $22.5 \%$ of those had learned by $15 \mathrm{~min}$ we have calculated that an additional $11.6 \%$ had heard the sirens. In a similar manner we calculate that at $15 \mathrm{~min} 1.1 \%$ who were initially notified by the media had heard the sirens. This leads to $35 \%$ as a reasonable assumption for the total portion of the population that was alerted by sirens in a 15 -min time frame.

Second, we assume that $69 \%$ of the TA radios functioned and aroused people. This assumption is based on the Hatch survey adjusted by the $97 \%$ arousal rate of TAs. A $50 \%$ informal alerting rate is also assumed based on results of a number of studies as identified in the Shearon Harris findings. The effectiveness of enhanced TA technologies is based on engineering estimates.

For the daytime scenario we used different assumptions. For sirens we used the results of the FEMA tests at fixed-site nuclear power plants. Overall the mean rate of warning receipt based on these tests is $85 \%$. For TA under the residential distribution policy we have used the same assumption as for nighttime adjusted for the percent of the population not at home who would not have received the warning. For TA under the $100 \%$ distribution option, we used the same assumption as for nighttime but adjusted for people in transit during peak travel times (8\%).

Table 8 .

The nighttime results are shown in Table 7, and the daytime results are in 
Table 7. Estimated 15-min notification rates: nighttime (expected percent warned)

\begin{tabular}{lcc}
\hline \multicolumn{1}{c}{ System } & Direct & With informal ${ }^{a}$ \\
\hline Siren $(10 \mathrm{~dB})$ & $35^{b}$ & 46 \\
Siren $(20 \mathrm{~dB})$ & $45^{c}$ & 57 \\
Siren $(85 \mathrm{~dB}$ at window $)$ & $?$ & $?$ \\
Tone alert & $69^{d}$ & 80 \\
Sirens $(10 \mathrm{~dB})$ and & 80 & 88 \\
tone alerts & $90^{e}$ & 95 \\
Enhanced tone alert & 94 & 97 \\
Sirens and enhanced tone alert & & \\
\hline
\end{tabular}

a50\%: Based on acceptance by Atomic Safety Licensing Board in Shearon Harris Nuclear Power Plant decision.

$b^{b}$ Based on experience at Nanticoke with first alert rate for sirens.

${ }^{c}$ Based on $10 \%$ additional arousal derived from testiniony at Shearon Harris.

${ }^{d}$ Based on alert rate from Hatch Nuclear Power Plant survey and Atomic Safety

Licensing Board finding of $97 \%$ arousal.

${ }^{e}$ Based on conservative engineering estimates.

Table 8. Estimated 15 -min notification rates: daytime (expected percent warned)

\begin{tabular}{llc}
\hline \multicolumn{1}{c}{ System } & Direct & With Informal $^{a}$ \\
\hline Siren $(10 \mathrm{~dB})$ & $85^{b}$ & 91 \\
Tone alert & $40^{c}$ & 52 \\
Sirens $(10 \mathrm{~dB})$ and tone alerts & 91 & 95 \\
Enhanced tone alert (residential) & $55^{d}$ & 63 \\
Sirens and enhanced & 93 & 96 \\
tone alert (residential) & & 91 \\
Enhanced tone alert (all) & $85^{e}$ & $99+$ \\
Sirens and enhanced tone alert (all) & 99 & \\
\hline
\end{tabular}

a50\%: Based on acceptance by Atomic Safety Licensing Board in Shearon Harris Nuclear Power Plant decision.

${ }^{b}$ Based on experience with rep.

${ }^{c}$ Based on alert rate from Hatch Nuclear Power Plant survey adjusted for percent at home $(60 \%)$. $(60 \%)$.

${ }^{d}$ Based on conservative engineering estimates and adjusted for percent at home $(8 \%)$.

${ }^{e}$ Based on conservative engineering estimates and adjusted for percent in transit 


\section{ANALYSIS}

\subsection{DISTRIBUTION OPTIONS}

The main rationale for the distribution policy recommended in the current planning standard was to achieve maximum warning coverage of the IRZ. Even given this mandate, the policy appeared excessive to some members of the planning subcommittee. The main logic for assessing the option to distribute one unit to private residences is that people primarily need the indoor warning when they are at home and asleep. A single unit would likely be sufficient to wake people in the sleeping area of a house. It is likely someone at home and awake would also hear the unit. The logic behind not distributing units to private buildings such as shops and industry are that people are in such buildings primarily during the day and would likely hear sirens. The previous analysis helps to demonstrate this. Our analysis indicates that $96 \%$ of the public would receive a notification in an emergency given the one unit per household distribution policy. The policy of mass distributing TAs would increase the likelihood of alert in a daytime scenario, although we could not demonstrate that it would produce a statistically significant increase in protection. Under this distribution policy, no measurable improvement would occur in a nighttime scenario.

\subsection{TECHNOLOGY OPTIONS}

The special TA offers a high degree of reliability, and the benefits of prompt notification are more likely to be achieved. The special TA technology provides a higher degree of indoor nighttime notification than does a commercial unit. When maintenance costs are factored in, the enhanced technology is clearly more cost effective than commercial units. If the maintenance of the commercial units is not done, the effectiveness of the units becomes very questionable. Effectiveness is likely to decrease by 10 to $20 \%$ per year (or greater). The "budget special" radio has the maintenance problems of the commercial unit and none of the benefits of the special unit. It is therefore not an attractive option.

\subsection{SIREN SUBSTITUTION OPTIONS}

\subsubsection{Raise The Standard}

One option would be to raise the standard for outdoor sirens from $10 \mathrm{~dB}$ to $20 \mathrm{~dB}$ over ambient. This option would be almost impossible to implement as it would require a very dense distribution of sirens and obtaining agreements to site them may be extremely time consuming and difficult. The benefits would also be small. It is estimated that the increase in arousal would only be an additional $10 \%$ greater than the proposed $10 \mathrm{~dB}$ requirement. The system would be inadequate for nighttime alerting. In addition, the system is unlikely to have significant marginal benefits under a daytime scenario. This option, therefore, is unlikely to provide an acceptable alternative to indoor alerting.

\subsubsection{Substitute Outdoor Sirens}

Another option would be to substitute outdoor sirens for indoor alerting in high population areas and distribute TA radios in less populated areas. This has a potential political problem of not being accepted by the people who do not receive the TA radios. The effectiveness based on whether this option would achieve indoor nighttime alerting is also somewhat uncertain. It is unclear whether an $85-\mathrm{dB}$ sound pressure would 
result in voice penetration of a structure. It is unlikely that it would be fully audible. This also may encourage people to leave their houses to hear a message. Originally the thinking was to have the outdoor messages tell people to go inside to listen to TA messages, which would no longer be feasible under this option. Additionally, outdoor warning systems designed under the existing standards, which FEMA has told the states to follow, may have to be redesigned for additional sirens. Furthermore, the estimates of sirens required would need to be verified at all sites. 


\section{CONCLUSIONS AND RECOMMENDATIONS}

The conclusion of this analysis is summarized in Table 9, which compares the costs and benefits of the most likely options to be adopted by CSEPP. Benefits as measured by the expected percentage of the population to receive an A\&N are different for a nighttime versus a daytime scenario.

Table 9. Summary of estimated costs and benefits

\begin{tabular}{|c|c|c|c|}
\hline Option & Incremental cost & Nighttime alert rate & Daytime alert rate \\
\hline Siren & $\begin{array}{l}\text { Baseline } \\
\left(\$ 6 \mathrm{M}^{a}\right)\end{array}$ & $46 \%$ & $91 \%$ \\
\hline $\begin{array}{l}\text { Siren/commercial tone alert } \\
\text { (residential distribution) }\end{array}$ & $+\$ 25 \mathrm{M}$ & $88 \%$ & $95 \%$ \\
\hline $\begin{array}{l}\text { Siren/enhanced tone alert } \\
\text { (residential distribution) }\end{array}$ & $+\$ 13 M$ & $97 \%$ & $96 \%$ \\
\hline $\begin{array}{l}\text { Siren/enhanced tone alert } \\
\text { (all distribution) }\end{array}$ & $+\$ 27 \mathrm{M}$ & $97 \%$ & $99 \%$ \\
\hline $20 \mathrm{~dB}$ siren & $+\$ 16 \mathrm{M}$ & $57 \%$ & $91 \%$ \\
\hline
\end{tabular}

${ }^{a}$ Estimated at $\$ 5.3 \mathrm{M}$ and rounded up. Source: Long, J. 1990. Memo to J. Sorensen, Oak Ridge National Laboratory, Oak Ridge, Tenn., August 28.

Given the evidence developed to date, it is recommended that a $10-\mathrm{dB}$ siren system plus the special or enhanced TA radios distributed to each residence and special institution in the IRZ be the A\&N standard of choice. This minimizes the cost of maintenance and the total cost of a TA radio system and still provides a high degree of reliability for indoor alerting. Furthermore, it reaches the population (residential/institutional) in greatest need of indoor alerting. 


\section{REFERENCES}

Ambrose, J. R. 1988. Record of Decision: Chemical Stockpile Disposal Program, Department of the Army, U.S. Department of the Army, Office of the Under Secretary, Washington.

Anstech, Schneider Engineers, and Oak Ridge National Laboratory. July 1990. "Chemical Stockpile Emergency Preparedness Program: System Design Criteria and Evaluation Guide for Public Alert and Notification Systems".

Carter, T. 1990. (ANSTECH, Inc.) Personal communication to J. Sorensen, Oak Ridge National Laboratory, Oak Ridge, Tenn., August 28.

Duclos, P., S. Binder, and R. Reister no date. Community Evacuation Following the Spencer Metals Processing Plant Fire, Nanticoke, Pennsylvania, unpublished report, U.S. Department of Health and Human Services, Atlanta, Ga.

Duclos, P., S. Binder, and R. Reister 1989. "Community Evacuation Following the Spencer Metals Processing Plant Fire, Nanticoke, Pennsylvania," Disasters 22, $1-11$.

ERCE, Inc. no date. A Preliminary Study of State of the Art Warning System Technology, Oak Ridge National Laboratory, Oak Ridge, Tenn.

Lindell, M., and R. Perry 1987. "Warning Mechanisms in Emergency Response Systems," Int. J. Mass Emergencies and Disasters 5(2), 137-153.

Long, J. 1990 (SE Technologies) Memo to J. Sorensen, Oak Ridge National Laboratory, Oak Ridge, Tenn., August 28.

Oak Ridge National Laboratory and Schneider Engineers 1990. Planning Guidance for the Chemical Stockpile Emergency Preparedness Program Final Interim Draft, U.S. Department of the Army and Federal Emergency Management Agency, Washington, April.

Sorensen, J., and D. Mileti 1990. Communication of Emergency Public Warnings, ORNL-6609, Oak Ridge National Laboratory, Oak Ridge, Tenn.

U.S. Army 1988. Final Programmatic Environmental Impact Statement for the Chemical Stockpile Disposal Program, Program Manager for Chemical Demilitarization, Aberdeen Proving Ground, Md.

23 NRC 294 1986. Atomic Safety and Licensing Board in the Matter of Carolina Power and Light Company, NRC Docket No. 50-400-0L. 


\section{INTERNAL DISTRIBUTION}

1. M. V. Adler

2. S. A. Carnes

3. Central Research Library

4-13. C. J. Coomer

14. E. D. Copenhaver

15. Document Reference Section

16. K. S. Gant

17. P. S. Gillis

18. R. K. Gryde:

19. J. O. Kolb

20. M. A. Kuliasha

21. Laboratory Records
22. Laboratory Records, RC

23. D. P. Lombardi

24. ORNL Patent Office

25. R. M. Reed

26. D. E. Reichle

27. R. B. Shelton

28. B. L. Shumpert

29-78. J. H. Sorensen

79. B. M. Vogt

80. B. A. Walker

81. A. P. Watson

\section{EXTERNAL DISTRIBUTION}

82-131. K. Blackman, Federal Emergency Mlanagement Agency, 500 C Street, SW, Washington, DC, 20472

132. B. G. Buchanan, Computer Science Department, University of Pittsburgh, 206 Mineral Industries Building, Pittsburgh, Pennsylvania, 15260

133-148. D. Fisher, U.S. Department of the Army, Office of the Assistant Secretary, Installations, Logistics, and Environment, The Pentagon, Washington, DC, 20310

149. A. Hirsch, President, Dynamac Corporation, The Dynamac Building, 11140 Rockville Pike, Rockville, Maryland, 20852

150. H. M. Ingram, Director, Udall Center for Studies in Public Policy, The University of Arizona, 803/811 East First Street, Tucson, Arizona, 85719

151. C. D. MacCracken, President, Calmac Manufacturing Corporation, 101 West Sheffield Avenue, P. O. Box 710, Englewood, New Jersey, 07631

152. D. E. Morrison, 333 Oxford Road, East Lansing, Michigan, 48823

153. Office of Assistant Manager for Energy Research and Development, DOE-ORO, P. O. Box 2001, Oak Ridge, Tennessee, 37831-8600

154. OSTI, U.S. Department of Energy, P. O. Box 62, Oak Ridge, Tennessee, 37831

166. J. B. Shrago, Director, Office of Technology Transfer, 405 Kirkland Hall, Vanderbilt University, Nashville, Tennessee, 37240

167. M. Williams, Professor, Department of Economics, Northern Illinois University, DeKalb, Illinois, 60115 

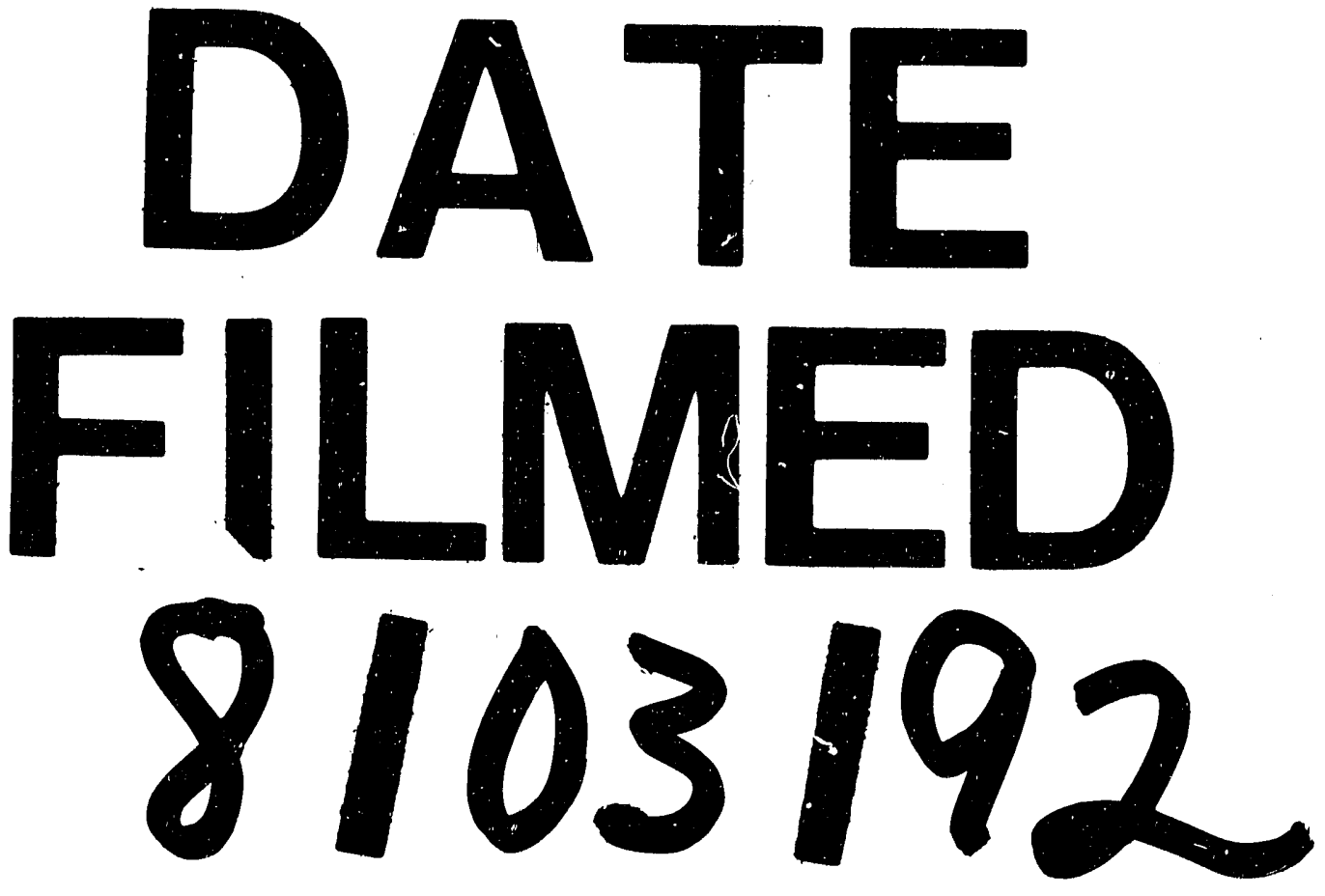
